\title{
New anti-HCV agents in the pipeline
}

\author{
Fabien Zoulim \\ From International Symposium HIV and Emerging Infectious Diseases 2014 \\ Marseille, France. 21-23 May 2014
}

Opportunities to treat infection with hepatitis $C$ virus $(\mathrm{HCV})$ are evolving rapidly. From the introduction of interferon $\alpha$ monotherapy in the early 90s' to the approval of telaprevir and boceprevir based triple therapies with pegylated interferon $\alpha$ and ribavirin in 2011, the chances of curing patients infected with $\mathrm{HCV}$ genotype 1 have improved dramatically to reach approximately $70 \%$. Significant further improvements, which may cure virtually all hepatitis $\mathrm{C}$ patients with an all oral, interferon-free regimen will become available in the very near future. These new direct acting antivirals (DAA) target the viral polymerase with either nucleoside analogues or non nucleosidic inhibitors, the viral protease, and the viral NS5A protein. Several clinical trials have now shown that a combination of sofosbuvir (nucleosidic polymerase inhibitor) with daclatasvir or ledipasvir (NS5A inhibitors), or sofosbuvir with simeprevir (protease inhibitor), or a combination of ABT-450 (proease inhibitor) with ritonavir (ABT-450/r), the nonnucleoside polymerase inhibitor ABT-333 and the NS5A inhibitor ABT-267, can achieve sustained virologic response in up to $95 \%$ of naive patients or previously treated patients, even in patients who failed prior treatment with first generation protease inhibitor. As these DAAs are becoming available in early access treatment programs, treatment strategy studies are being performed to optimize treatment regimens with respect to the choice of DAAs and treatment duration, based on viral genotypes, prior treatment exposure, and the presence of liver cirrhosis. The next challenge will be to identify HCV infected patients in the general population and to facilitate access to treatment.

Published: 23 May 2014
doi:10.1186/1471-2334-14-S2-S15

Cite this article as: Zoulim: New anti-HCV agents in the pipeline. BMC

Infectious Diseases 2014 14(Suppl 2):S15.
Submit your next manuscript to BioMed Central and take full advantage of:

- Convenient online submission

- Thorough peer review

- No space constraints or color figure charges

- Immediate publication on acceptance

- Inclusion in PubMed, CAS, Scopus and Google Scholar

- Research which is freely available for redistribution
( Biomed Central Attribution License (http://creativecommons.org/licenses/by/4.0), which permits unrestricted use, distribution, and reproduction in any medium, provided the original work is properly cited. The Creative Commons Public Domain Dedication waiver (http:// creativecommons.org/publicdomain/zero/1.0/) applies to the data made available in this article, unless otherwise stated. 